\title{
Berichtigungen und Ergänzungen für die nächste Ausgabe
}

\author{
Bitte an Verlag Walter de Gruyter \& Co., \\ Berlin W 35, Genthiner Str. 13, einsenden
}

Name und Vorname:

Geburtsdatum (Jahr, Monat, Tag):

Stellung :

Lehrgebiet:

Genaue Adresse:

b. w. 
Anschriften fehlender Gelehrter 
Verzeichnis der Gelehrten 
